\title{
LEACHABLE VOLATILE ORGANIC COMPOUNDS FROM POLYETHYLENE PLUMBING PLASTIC PIPES: A CASE STUDY OF MEDINA AL MUNAWARAH, SAUDI ARABIA
}

\author{
Muhammad Mansoor Shaikh1, Awadh 0. AlSuhaimi' ${ }^{1}$, Marlia M. Hanafiah ${ }^{2,3^{*}}$, Muhammad Aqeel Ashraf ${ }^{3,4}$, Ahad Fantoukh"1, Eman AlHarbi ${ }^{1}$ \\ ${ }^{1}$ Chemistry Department, Taibah University, P.0.Box 30002, Almadinah AlMunawarah \\ ${ }^{2}$ School of Environmental and Natural Resource Sciences, Faculty of Science and Technology, Universiti Kebangsaan Malaysia, 43600 Bangi, \\ Selangor, Malaysia ${ }^{3}$ International Water, Air \& Soil Conservation Society, 59200 Kuala Lumpur, Malaysia \\ ${ }^{4}$ Department of Environmental Science and Engineering, School of Environmental Studies, China University of Geosciences
}

*Corresponding Author: mhmarlia@ukm.edu.my; Tel.: 03-89215865; fax: +603-89253357

This is an open access article distributed under the Creative Commons Attribution License, which permits unrestricted use, distribution, and reproduction in any medium, provided the original work is properly cited.

\begin{abstract}
ARTICLE DETAILS
ABSTRACT

Articlehistory:

Received 12 August 2016

Accepted 12 December 2016

Available online 17 february 2017

The widespread of plastic piping applications in water distribution systems and home plumbing network has brought many health concern dues to the water quality deterioration from the occurrence of leachable organic pollutants into tape water. Among these pollutants, volatile organic molecules are believed to migrate easily from the popular polyethylene piping. This study aimed to screen the occurrence of volatile organic compounds leachable from plastic pipes comprising home water network system in residential homes located in Medina $\mathrm{Al}$ Munawarah city. For this purpose, a total of 28 water samples were collected from different houses of various ages. The presence of Ethyl methacrylate, 1,2Dichloroethane, Dibromochloromethane, 1,2,3Trichloroethene, Xylene, pyridine ,1,1,2,2Tetrachloroethane, Benzyl chloride, 1,2Dichlorobenzene and 2Picoline were analysed. Although some of the levels of the pollutants studied were within the allowed limit, however, the level of 1,2Dichloroethane, 1,2,3Trichloroethane and 1,2Dichlorobenzene exceeded the pe rmissible levels in $62.07 \%$, $10.34 \%$ and $13.79 \%$ of homes, respectively. The leachability study that was conducted to correlate volatile organic contaminants to plastic pipes, indicated that all the volatile compounds were migrated from the widely used polyethylene pipes. However, apart from benzyl chloride and 1, 2 dichloroethane which were detected in low levels, the other compounds not being found in source water. This initial screening confirmed that the plastic piping could be considerable source for the contamination of tape water with volatile organic compounds.
\end{abstract}

\section{KEYWORDS}

Volatile organic compound; water quality; human health; piping materials; Saudi Arabia

\section{INTRODUCTION}

The application of plastic materials for many purposes in daily life has increased steadily in recent years. Recent decades have seen the advance of synthetic premise plumbing materials, which replaced the use of other materials in homes including pipes constructing the water distribution systems. Presently plastic pipes makeup to $54 \%$ of all the pipes installed worldwide [1]. These materials became popular due to many characterized properties such as light weight, easy to transport, resistance against trauma, etc. In the last years, many evidences from research showed that the synthetic materials such as plastic pipes could be potential sources for various leachable organic pollutants like volatile and semi volatile organic compounds (VOCs) [2]. These fragments which believed to be released from the additive agents to the polymer materials during synthesis can alter the taste and odour of drinking water, thus diminishing water quality and consequently impair human health. The measurement of migration of organic residues from pipes materials varies and depends among several factors such as on the polymer composition, operating temperature and the antioxidant additives. The organism that grows on pipe surface, lining materials and water chemistry also can contribute to the leaching process [3]. For instance, according to a research, polystyrene might release residual styrene monomer and VOCs at room temperature including pentane, benzene, toluene, ethyl benzene, xylene, isomers and benzyl chloride. The degradation, products of metabolism released by microorganisms grow on the pipe surfaces and derivatives of hydrocarbons with functional oxygen groups (e.g. ester and aldehydes) can be migrated into water from damaged polyethylene chains. 2,6di-tert-butylbenzoquinone. Principally, these compounds are originated from the degradation of antioxidants with the following trade names, Irgafos 168 and Irganox 1010.

\section{METHODOLOGY}

\subsection{Water and Pipes Samples}

Twenty-eight water samples from houses within Medina residential areas were collected from different location. Samples were collected in one-litre amber glass bottle in the morning by house occupying persons to allow pipe incubated with water samples for at least 6 hours. To verify if the sources contain any of the investigated VOCs, 10 water samples were also collected from the domestic distribution network source before entering the residential house [4]. To confirm that the source of the targeted VOCs in plastic piping used in home water distribution system, samples of the commonly utilized crosslink polyethylene PEX plastic pipes (inner diameter $16 \mathrm{~mm}$ ) were purchased from local shops in Medina Al-Munawarah and used to investigate leaching process. For this purpose, pipes were flashed three times with reagent (MilliQ water) UV 


\subsection{Samples Preparation and Determination of Volatile Compounds}

Preparation of samples was done with solid phase extraction (SPE) using HBL3 CC/60 mg cartridge with standard ASE-12 head manifold Auto Science (EPA following the official EPA method 8270D). Briefly, the cartridges were pre-cleaned twice with $2 \mathrm{ml}$ acetone and $2 \mathrm{ml}$ distilled water, then three time with Dichloromethane (DCM). $100 \mathrm{ml}$ sample of $\mathrm{pH}-2$ was loaded to the cartridge at pressure of 25psi. Cartridge was dried with nitrogen and trapped volatile compounds were eluted with $1 \mathrm{ml}$ of dichloromethane with oven dry sodium sulphate. In the same way, another $100-\mathrm{ml}$ water sample of $\mathrm{pH}-12$ was loaded to another cartridge followed by the same procedure. Both elution was mixed and analysed by gas chromatography flame ionization detector (GCFID) as shown in Table 1. The thermos GC model 1300 gas chromatography equipped with flam ionized detector, and at operating condition with column (Rtx $30 \mathrm{~m} \times$ $0.25 \mathrm{~mm} \times 0.25 \mu \mathrm{m}$ ) was used to determine the volatile compounds in the water samples. The same procedure was repeated with incubated water from plastic pipes after adjusted $\mathrm{pH}-2$ and $\mathrm{pH}-12$. These procedures were conducted to measure concentration of volatile organic contaminants leached from plastic pipes.into water source.

Table 1: Operating condition for GCFID

\begin{tabular}{ll}
\multicolumn{2}{l}{ Table 1: Operating condition for GCFID } \\
\hline Item & Operating condition \\
\hline Carrier gas & Hydrogen (H) \\
Column type & Rtx $30 \mathrm{~m} \times 0.25 \mathrm{~mm} \times 0.25 \mu \mathrm{m}$ \\
Column Oven & Initial $45^{\circ} \mathrm{C}$, hold 4 minutes, ramp $10^{\circ} \mathrm{C} /$ minute to $200^{\circ} \mathrm{C}$, hold 5 minutes, ramp $15^{\circ} \mathrm{C} / \mathrm{min}$
\end{tabular}

\begin{tabular}{ll}
\hline Injection volume & $2 \mu \mathrm{l}$ \\
SSL injector & $250^{\circ} \mathrm{C}$ : Carrier gas $\mathrm{H}$ in split mode with split ratio of 100 \\
Column flow & $1.2 \mathrm{ml} / \mathrm{min}$ \\
Detection limit & Less than one microgram per litre or $\mathrm{ppb}(<1 \mu \mathrm{g} / L)$
\end{tabular}

Detection limit Less than one microgram per litre or $\mathrm{ppb}(<1 \mu \mathrm{g} / \mathrm{L})$

\section{RESULTS AND DISCUSSION}

\subsection{Concentration of volatile organic compounds from tap water samples}

A total of 28 tap water samples from different houses with ages ranged from less than one year to around twenty years within Medina Al-Munawarah residential area were collected and analysed for volatile organic compounds. The monitored volatile compounds found in the present study were Ethyl methacrylate, 1,2Dichloroethane, Dibromochloromethane, 1,2,3Trichloroethene, Xylene, Pyridine 1,1,2,2 Tetrachloroethane, Benzyl chloride, 1,4dichlorobenzene, and 2Picoline. Figure 1 shows the concentration of VOCs in tap water samples collected from different houses

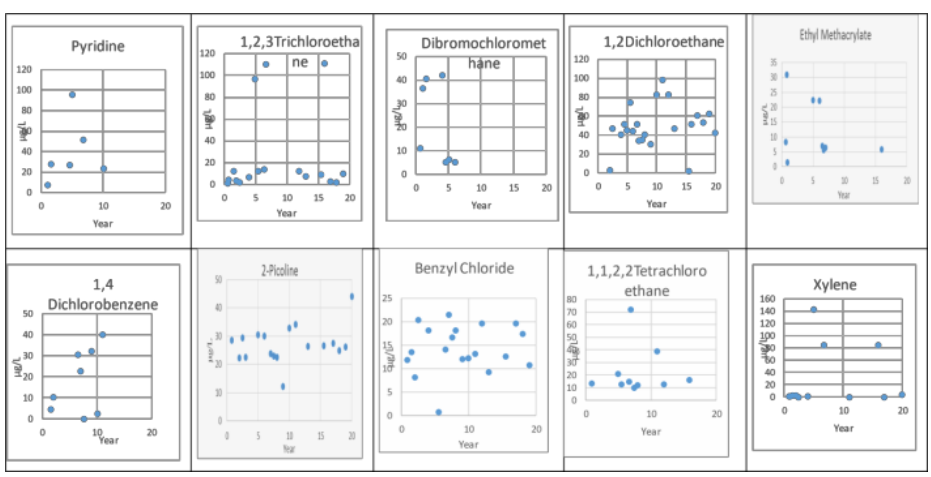

The concentration of Dibromochloromethane was found in $24.14 \%$ of water samples collected from homes that were inhabited for 6 years ago, ranged from 5 to $42 \mu \mathrm{g} / \mathrm{L}$ with an average of $17.53 \mu \mathrm{g} / \mathrm{L}$. The level of dibromochloromethane was below the maximum contamination limit allowed by EPA $(60 \mu \mathrm{g} / \mathrm{L})$. Dibromochloromethane may leached from pipes when chlorine react with other naturally occurring chemical substance in water. Ethyl methacrylate was monitored in $31 \%$ of samples in the range of 1.4 to $31 \mu \mathrm{g} / \mathrm{L}$ with an average of $12.22 \mu \mathrm{g} / \mathrm{L}$. The compound was detected mainly in water samples collected from home between the ages of 1 to 10 years old. EPA and other official international bodies do not regulate the limit of ethyl methacrylate in water, however, there is no available information in the literature concerning its health effects on humans. Previous investigation indicated that this volatile molecule might be leached from PEX pipes. 1,2 dichloroethane was found mainly in homes above 2 years old with concentrationranged,from 2 to 98.4 $\mu \mathrm{g} / \mathrm{L}$ (average of $49.25 \mu \mathrm{g} / \mathrm{L}$ ).

The level of 1,2dichloroethane in most of samples (75\%) exceeded the allowed limit of WHO (30 $\mu \mathrm{g} / \mathrm{L})$. This permissible limit of WHO $(70 \mu \mathrm{g} / \mathrm{L}))$. Xylene was detected in $41.37 \%$ of water samples and ranged from 0.08 to $143.2 \mu \mathrm{g} / \mathrm{L}$ (average value of $27.35 \mu \mathrm{g} / \mathrm{L}$ ). This molecule was conformed in samples collected from home of all ages. The xylene concentration in all samples are within permissible limit stated by EPA $(10000 \mu \mathrm{g} / \mathrm{L})$. Xylene mixture are used to make plasticizers, polyester, fibre phthalate, film and fabricated [5]. Pyridine compound was found in $34.48 \%$ of water samples with a range of 7.2 to $96 \mu \mathrm{g} / \mathrm{L}$ and the average value of $36.68 \mu \mathrm{g} / \mathrm{L}$. This volatile compound was monitored in samples from homes of all ages. The permissible limits of pyridine in drinking water was not regulated by WHO and EPA or other organisations, although there are many health concerns about its harmful effects including damage liver, neurological disorders, renal diseases and irritation.

Former studies on the leaching of organic compounds from plastic piping indicated that pyridine is likely to be released from PEX pipes. 1,1,2,2tetrachloroethane was quantified in $34.48 \%$ of water samples ranged from 9.4 to $72 \mu \mathrm{g} / \mathrm{L}$ and average value of $21.96 \mu \mathrm{g} / \mathrm{L}$. This compound was found in the samples from houses between the ages of 1 to 16 years. Its concentration in all samples is within the permissible limit stated by WHO $(40 \mu \mathrm{g} / \mathrm{L})$, except for one sample collected from the house in the age of 7 years. Benzyl chloride residues were found in the range of 0.8 to $21.6 \mu \mathrm{g} / \mathrm{L}$, with an average value of $14.29 \mu \mathrm{g} / \mathrm{L}$. This compound was monitored in water samples from homes of all ages. The volatile organic compound, 1,4 dichlorobenzene was found in $28.57 \%$ of water samples collected in a range of 0.2 to $40 \mu \mathrm{g} / \mathrm{L}$ and average value of 17.77 $\mu \mathrm{g} / \mathrm{L}$. This compound was monitored in water samples from houses between the ages of 1 to 17 years. The concentration in $14.28 \%$ of the samples was above the allowed limit stated by EPA $(7.5 \mu \mathrm{g} / \mathrm{L})$. chlorobenzene which also referred to as para-DCB could led to liver, kidney or spleen damage. Similarly, 2-picoline compound was found in $62 \%$ of the water samples ranged from 12.2 to $44 \mu \mathrm{g} / \mathrm{L}$ with an average value $27.1 \mu \mathrm{g} / \mathrm{L}$. This compound was monitored in water samples from homes of all ages. In addition to the above compounds, some other organic contaminants such allyl chloride, chloroform1,1,1, trichloroethane, toluene, benzene and chloroethanol were also detected in trace amounts in some water samples. The variations of VOCs concentrations between samples collected from homes with different ages might be attributed to network length, size, plastic quality and incubation time. Direct exposure to sun light and temperature of the pipes are different from one home to another. However, there is no clear evidence for any correlation between house age and contamination level. Figure 2 shows the mean and standard deviation of VOCs concentration in tap water samples.

Figure 1: VOCs concentration in tap water samples 


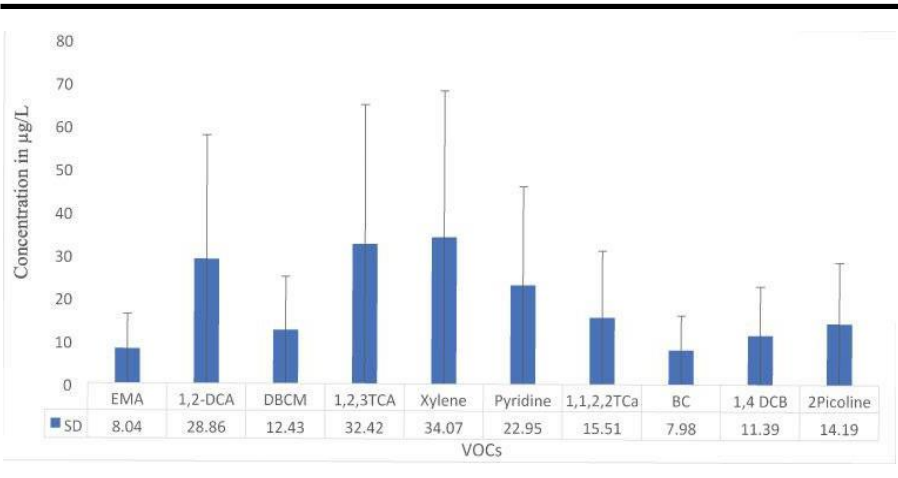

Figure 2: Mean and standard deviation of VOCs concentration in tap water

\subsection{Leaching of volatile organic compounds from plastic pipes}

To correlate the source for the organic compounds determined in water samples, the leaching ability of the targeted pollutants from the most popular plastic pipes PEX was investigated. Figures 3 and 4 show the leaching of VOCs from plastic pipes samples in the water distribution system and the mean and standard deviation of VOCs concentration in plastic pipe samples, respectively. Other trace compounds such as benzene, toluene, alcohol and chloroform were also monitored.

Ten volatile organic compounds (VOCs) were determined in most popular brands in Saudi Arabia crosslink polyethylene (PEX) plastic pipes. The concentration of Ethyl methacrylate was ranged from 4.4 to $13.4 \mu \mathrm{g} / \mathrm{L}$ with an average of $7.53 \mu \mathrm{g} / \mathrm{L}$. Whereas, the concentration of 1,2dichloroethane was found between 2.2 to $17.8 \mu \mathrm{g} / \mathrm{L}$, with an average of $8.26 \mu \mathrm{g} / \mathrm{L}$. The concentrations of $1,2,3$ trichloroethane, xylene, pyridine, 1,1,2,2tetrachloroethane, isobutyl alcohol, 1,2dichloromethane, 1,4 dichlorobenzene and carbon disulphide were ranged from 3.6 to 28.8 $\mu \mathrm{g} / \mathrm{L}, 0.6$ to $51.2 \mu \mathrm{g} / \mathrm{L}, 24$ to $42 \mu \mathrm{g} / \mathrm{L}, 4$ to $44 \mu \mathrm{g} / \mathrm{L}, 13.4$ to $36 \mu \mathrm{g} / \mathrm{L}, 5$ to $19.2 \mu \mathrm{g} / \mathrm{L}, 0.08$ to $7.6 \mu \mathrm{g} / \mathrm{L}$ and 0.4 to $43.2 \mu \mathrm{g} / \mathrm{L}$, respectively. Incubation that was conducted for three days found that the concentration of volatile compounds increases with the increasing of incubation time. Isobutyl alcohol, 1,2dichloromethane and carbon disulphide compounds were found in the plastic pipes, however, not detected in tap water analysis.

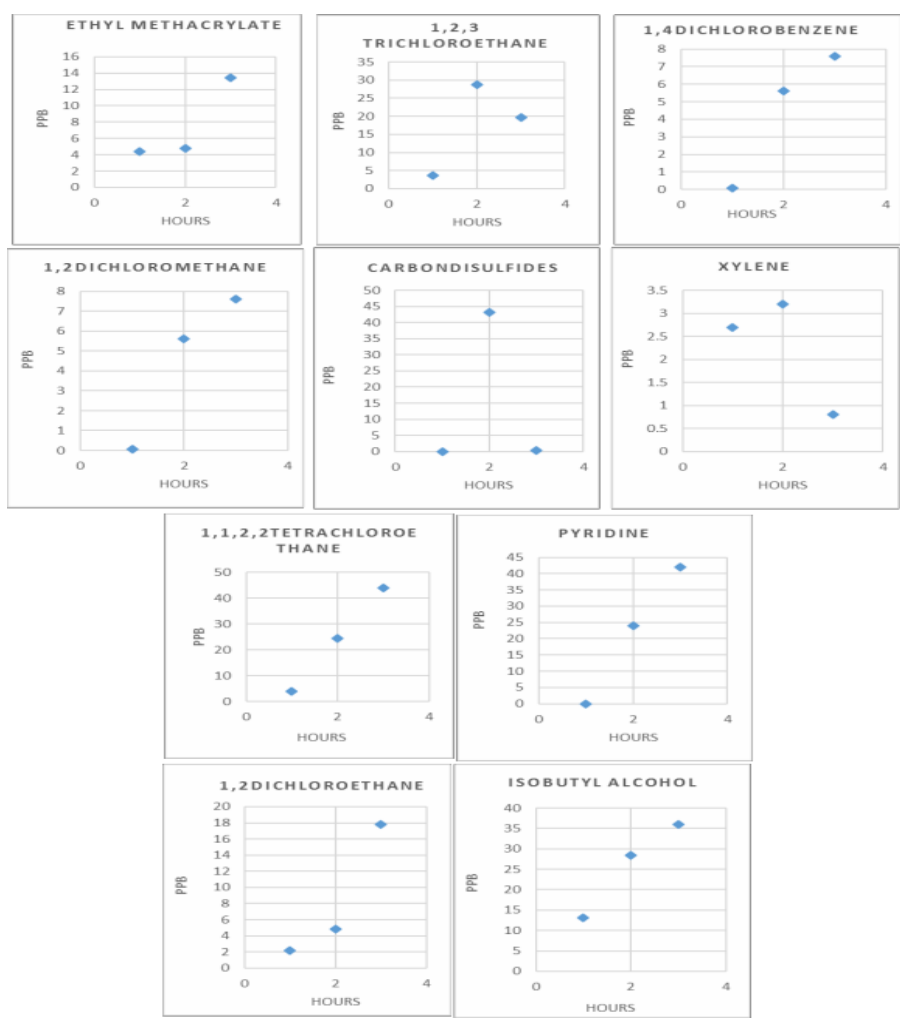

Figure 3: Leaching of VOCs from plastic pipes samples in the water distribution system

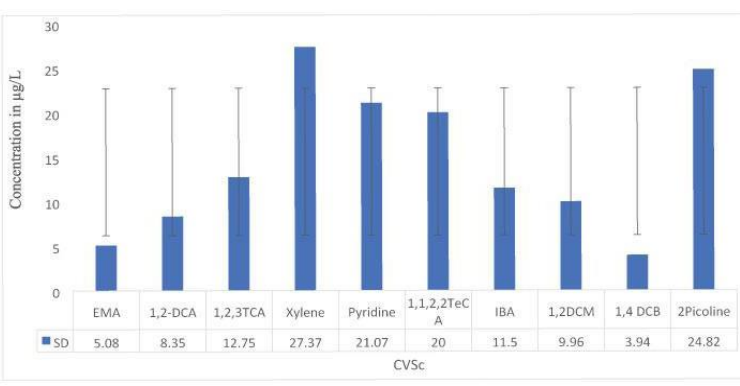

Figure 4: Mean and standard deviation of VOCs concentration in plastic pipes samples

\section{CONCLUSION AND RECOMMENDATION}

Present study reveals that the possibility of contamination of volatile organic compounds leaching through plastic pipes network of residential houses is high. The concentration of different compounds obtained in this study irrespective of the types of home (new or old building) of different their ages are far above the health based WHO guideline limits. It was found that the concentration of different compounds in water samples collected from different houses (old and new) in Medina Al- Munawwarah were contaminated with one or more volatile organic compounds. These preliminary findings provide clear indication pertaining to water contamination due to leaching from plastic piping and plumbing materials in residential or domestic water network in selected study areas located in Medina Al- Munawwarah. However, this aspect needs further detailed investigation and analysis because this issue is perilous in relation to public health.

\section{REFERENCES}

[1] Adams, W.A., Xu, Y., Little, J. C., Fristachi, A. F., Rice, G. E., and Impellitteri, C. A. 2011. Predicting the migration rate of dialkyl organotin from PVC pipe into water. Environmental Science \& Technology, 45(16), 6902-6907.

[2] Al-alack, M. H., Sheikheldin, S. Y., Fayad, N. M., and Khaja, N. 2000. Effect of water quality parameters on the migration of vinyl chloride monomer from unplasticized PVC pipes. Water Air and Soil Pollution., 120 (1-2), 195-208.

[3] Bocca, D., Arvin, E., and Mosbæk, H. 2002. Identification of organic compounds migrating from polyethylene pipelines into drinking water. Water Research, 36(15), 3675-3680.

[4] Bucheli-Witschel, M., Kotzsch, S., Darr, S., Widler, R., \& Egli, T. 2012. A new method to assess the influence of migration from polymeric mater on the bio stability of drinking. Water Research, 46(13), 4246-4260.

[5] Durand, M. L., \& Dietrich, A. M. 2007. Contributions of silane cross-linked PEX pipe to chemical/solvent odor's in drinking water. Water Science \& Technology, 55(5), 153-160. 